\title{
COMPARATIVE ASSESSMENT OF THE EMISSION CHARACTERISTICS OF FIRST, SECOND AND THIRD GENERATION BIODIESELS AS FUEL IN A DIESEL ENGINE
}

\author{
Upendra Rajak ${ }^{1}$, Prerana Nashine ${ }^{2}$, Tikendra Nath Verma ${ }^{3,{ }^{*}}$
}

\begin{abstract}
The present study aims to investigate emission characteristics with the B20 blend level of first, second and third generation biodiesels. The engine, a naturally aspirated, single cylinder, diesel engine, was operated at 1500 $\mathrm{rpm}$ engine speed and at different engine loads with intervals of $25 \%$. Also, the engine is analyzed by Diesel-RK mathematical tool and emission characteristics such as smoke, carbon dioxides (CO2), particulate matter (PM), nitric oxide (NO) and summary of emission (SE) were obtained. Numerical simulation is performed using pure diesel (D100), first, second and third generation B20 (80\% diesel $+20 \%$ biodiesel). Results of reduction in emissions for biodiesel blend were found to be lower than diesel fuel as smoke (BSN) by $54.68 \%$ for jojoba, PM by $4.8 \%$ for coconut, $52.0 \%$ for jojoba and $7.1 \%$ for fish oil, NO by $38.2 \%$ for jatropha curcas, and SE by $8.8 \%$ for soybean, $12.9 \%$ for jatropha curcas and $8.8 \%$ for spirulina but carbon dioxides was found to be higher by $0.38 \%$ for rapeseed, $0.61 \%$ for fish oil. The blend of B20 shows a decrease in emissions at $1500 \mathrm{rpm}$ with $100 \%$ engine load. The numerical results are verified against experimental results conducted under the same operating conditions.
\end{abstract}

\section{Keywords: Compression ignition engine; Biodiesel; Emission; Numerical}

\section{INTRODUCTION}

Biodiesel is an alternative and renewable fuel for compression ignition engine, can be formed from different categories of edible and non-edible vegetable oils from first, second and third generation renewable fuel. The special effects on exhaust gas emissions such as smoke, unburnt hydrocarbon (UHC), carbon monoxide (CO), carbon dioxides (CO2), Nitric oxide (NO) and particulate matter (PM) emissions and slightly reduced engine performance using biodiesel as an alternative fuel in place of petroleum fuel [1-3]. The effect of emission parameter on a direct injection diesel engine using five different categories of biodiesel is investigated. The results show reduction in $\mathrm{NO}_{\mathrm{X}}$ by $31.2 \%$ of chicken fats, PM emission by $93.78 \%$ for poultry fats and reductions in smoke emission by $93.8 \%$ for sunflower at full load condition [20]. The effect of microalgae Chlorella protothecoides with diesel is evaluated and compared on a 4-stroke, single-cylinder air-cooled diesel engine at different engine speeds. Results found are reduction in performance with brake power by $7.0 \%$, torque by $4.9 \%$, exhaust gas temperature by $6.1 \%$ and emission of CO by $28 \%, \mathrm{CO} 2$ by $4.2 \%$ and NOX by $7.4 \%$, but increase in fuel consumption by $10.2 \%$ and $\mathrm{O} 2$ by $15.8 \%$ for microalgae chlorella protothecoides (B100) as compared to diesel (D0) [21].

Investigated the effect of ternary blends (diesel + cotton oil $+n$-butanol) as a volume basis at different engine speed $(1800 \mathrm{rpm}$ to $4400 \mathrm{rpm})$ on a direct injection turbocharged diesel engine. The results show that reduction in thermal brake efficiency (BTE), brake power (BP), brake torque (BT), and exhaust gas temperature (EGT), but increase of fuel consumption with increasing blend ratio of $n$-butanol. The emission parameters show the reduction in $\mathrm{CO}$, UHC, but increase in oxides of nitrogen ( $\mathrm{NO}$ and $\mathrm{NO} 2$ ). Higher reduction in $\mathrm{CO}$ and $\mathrm{UHC}$ emissions in $30 \%$ diesel $+10 \%$ cotton oil $+60 \%$ n-butanol and $20 \%$ Diesel $+20 \%$ cotton oils $+60 \%$ n-butanol blends and increase of fuel consumption [22]. The utilization of $10 \%, 15 \%$, and $20 \%$ pentanol and Calophyllum inophyllum (CI) biodiesel blend on a water-cooled, direct-injection diesel engine is investigated for performance, emission, and combustion parameters at different engine speeds (1200 rpm to $2400 \mathrm{rpm}$ ). The results show that the addition of pentanol with CI 20 in blend improved fuel properties. Also, thermal efficiency and engine power are higher and fuel consumptions lowered by using $15 \%$ and $20 \%$ blends of pentanol as compared to CI20. The emission parameters are slightly increase, such as NO, CO and UHC for $15 \%$ and $20 \%$ blends of pentanol and a significant This paper was recommended for publication in revised form by Regional Editor Yasin Karagöz

${ }^{1}$ Department of Mechanical Engineering, Rajeev Gandhi Memorial College of Engineering and Technology Nandyal- 518501, India ${ }^{2}$ Department of Mechanical Engineering, National Institute of Technology Rourkela-769008, India

${ }^{3}$ Department of Mechanical Engineering, Maulana Azad National Institute of Technology Bhopal-462003, India

*E-mail address: verma.tikks@gmail.com; tnverma@manit.ac.in

Orcid id: 0000-0002-3884-8758, 0000-0002-6555-3306, 0000-0002-1156-0412

Manuscript Received 11 July 2018, Accepted 29 August 2018 
reduction in smoke emission but better than CI 20 blend ratio [23]. Evaluated effects of water (5, 10 and 15\%) and biodiesel $(10,20,30$ and 40\%) addition with diesel at engine speeds (1000, 2100 and $3000 \mathrm{rpm})$ with a load of 20\%, $50 \%$ and $80 \%$. The thermal efficiency, fuel consumption, carbon monoxide emissions increase and exhaust gas temperature, smoke emission and NOX are reduced emission with increasing water percentage [25].

A number of studies was carried out investigating the blend ratio of diesel and biofuels on CI engine combustion, performance and emission at different operating conditions. In this respect, the present study carried out to investigate the emission characteristics and comparison of emulsion B20 ( $80 \%$ diesel $+20 \%$ biodiesel) of a diesel engine by using three different categories of biofuels from first, second and third generation. Thus, the primary ambition of present investigation is to emphasize the enormous potential of biodiesel as the renewable energy source in the transport industry and potential to avoid the energy and environment crisis.

\section{MATERIAL AND METHOD Fuel Properties}

The Alternative fuel properties (first, second and third generation) are one of the key reasons responsible for the quality of fuel mixing rate and burning procedure. Fuel density, viscosity, fuel calorific value, cetane number, and flash point are the properties dependably emphasized by researchers to define the effects of an alternative additive on emission characteristics of a diesel engine [1-17, 29]. Properties of the first (coconut, palm, rapeseed, and soybean), second (cottonseed, jatropha, jojoba, and Karanja), and third (fish oil, microalgae spirulina, waste oil and animal fats) generation biodiesel feedstocks are shown in Table 1, Table 2 and Table 3. The blended fuel properties as shown in Table 4.

Table 1. First generation biodiesel [1-7]

\begin{tabular}{|l|l|l|l|l|}
\hline Properties & Coconut & Palm & Rapeseed & Soybean \\
\hline Density $\left(\mathrm{kg} / \mathrm{m}^{3}\right)$ at $40{ }^{\circ} \mathrm{C}$ & 872.1 at $303 \mathrm{~K}$ & $860-900$ & $874-920.9$ & 887 at $15{ }^{\circ} \mathrm{C}$ \\
\hline Viscosity $\left(\mathrm{mm}^{2} / \mathrm{s}\right)$ at 40 & 2.80 at $313 \mathrm{~K}$ & 4.42 & $6.92-34.32$ & $4-4.63$ \\
\hline Calorific value $(\mathrm{MJ} / \mathrm{kg})$ & 37.785 & $34-36.77$ & $36.7-40.5$ & 37.53 \\
\hline Cetane number & 60 & $62-63$ & $49.5-54.4$ & 51 \\
\hline Flash point $\left({ }^{\circ} \mathrm{C}\right)$ & 391 & 174 & 236 & $>120$ \\
\hline
\end{tabular}

Table 2. Second generation biodiesel [2, 8-11]

\begin{tabular}{|l|l|l|l|l|}
\hline Properties & Cottonseed & $\begin{array}{l}\text { Jatropha } \\
\text { curcas }\end{array}$ & Jojoba & Karanja \\
\hline Density $\left(\mathrm{kg} / \mathrm{m}^{3}\right)$ at $40{ }^{\circ} \mathrm{C}$ & $874-911$ & $863.6-873$ & $863-866$ & $876-890$ \\
\hline Viscosity $\left(\mathrm{mm}^{2} / \mathrm{s}\right)$ at 40 & $4-6.37$ & $4.78-6.71$ & $19.2-25.4$ & $4.37-9.60$ \\
\hline Calorific value $(\mathrm{MJ} / \mathrm{kg})$ & $39.5-40.1$ & $39.8-42$ & $42.76-47.38$ & $36-38$ \\
\hline Cetane number & $41.2-59.5$ & $57.2-63$ & 63.5 & $52-58$ \\
\hline Flash point $\left({ }^{\circ} \mathrm{C}\right)$ & $210-243$ & 238 & 292 & $163-187$ \\
\hline
\end{tabular}

Table 3. Third generation biodiesel [1, 12-17]

\begin{tabular}{|l|l|l|l|l|}
\hline Properties & Fish oil & Spirulina & $\begin{array}{l}\text { Waste } \\
\text { cooking oil }\end{array}$ & Animal fats \\
\hline Density $\left(\mathrm{kg} / \mathrm{m}^{3}\right)$ at $40{ }^{\circ} \mathrm{C}$ & $870-885$ & 860 & 871 at $20^{\circ} \mathrm{C}$ & 882.5 \\
\hline Viscosity $\left(\mathrm{mm}^{2} / \mathrm{s}\right)$ at 40 & $4.14-4.74$ & 5.66 & 4.6 & 6.3 \\
\hline Calorific value $(\mathrm{MJ} / \mathrm{kg})$ & $40.05-41$ & 41.36 & 37.5 & 39.93 \\
\hline Cetane number & $51.5-52.6$ & - & 51 & 52.34 \\
\hline Flash point $\left({ }^{\circ} \mathrm{C}\right)$ & $114-173$ & 130 & 453 & - \\
\hline
\end{tabular}


Journal of Thermal Engineering, Research Article, Vol. 6, No. 6, Special Issue 12, pp. 211-225, December, 2020

Table 4. B20 blend for first, second and third generation of biodiesels

\begin{tabular}{|l|c|c|c|c|c|}
\hline \multicolumn{1}{|c|}{ Fuel } & $\begin{array}{c}\text { Density }\left(\mathbf{k g} / \mathbf{m}^{\mathbf{3}}\right) \\
\mathbf{a t} \mathbf{4 0}{ }^{\circ} \mathbf{C}\end{array}$ & $\begin{array}{c}\text { Viscosity }\left(\mathbf{m m}^{\mathbf{2}} \mathbf{s}\right) \\
\mathbf{a t ~}_{\mathbf{4 0}}{ }^{\circ} \mathbf{C}\end{array}$ & $\begin{array}{c}\text { Calorific } \\
\text { value } \\
(\mathbf{M J} / \mathbf{k g})\end{array}$ & $\begin{array}{c}\text { Cetane } \\
\text { number }\end{array}$ & $\begin{array}{c}\text { Flash } \\
\text { point } \\
\left({ }^{\circ} \mathbf{C}\right)\end{array}$ \\
\hline D100 & 830 & 2.8 & 42.5 & 48 & 74 \\
\hline BC20 & 838.75 & 2.8 & 41.51 & 50.49 & 137.4 \\
\hline BPA20 & 836.24 & 3.06 & 40.73 & 50.91 & 94 \\
\hline BRA20 & 839.2 & 3.35 & 41.3 & 49.33 & 106 \\
\hline BSO20 & 841.85 & 3.0 & 41.46 & 48.47 & 83.2 \\
\hline BCO20 & 839.2 & 3.0 & 41.87 & 50.4 & 101.2 \\
\hline BJA20 & 836.98 & 3.12 & 41.93 & 49.92 & 106.8 \\
\hline BJO20 & 836.86 & 4.12 & 42.55 & 51.22 & 117.6 \\
\hline BKA20 & 839.56 & 3.06 & 41.14 & 48.83 & 91.8 \\
\hline BFA20 & 833.2 & 3.03 & 41.9 & 48.95 & 82 \\
\hline BSP20 & 836.24 & 3.22 & 42.26 & - & 85.2 \\
\hline BWC20 & 838.52 & 3.1 & 41.46 & 48.62 & 149.8 \\
\hline BAF20 & 840.92 & 3.29 & 41.96 & 48.91 & - \\
\hline
\end{tabular}

\section{Experiment Method}

The engine was operated with different engine load with a step of $25 \%$ and regular diesel at $1500 \mathrm{rpm}$ constant speed to achieve an engine steady state condition. After achieving the steady-state condition and with three- times repeatability of readings, data were recorded into the data-acquisition system. After completing the test for one test fuel, the engine was run after a few minutes to ensure the achievement the steady-state condition and prediction of test results considering average of three times reading for diesel fuel. Test engine is illustrated in Fig. 1 and Test conditions are shown in Table 5. The single cylinder diesel engine connected eddy current dynamometer in present study for proposed tool validation. An eddy current dynamometer of $10 \mathrm{~kg}$ capacity with maximum output of $3.5 \mathrm{~kW}$ is used for this study.

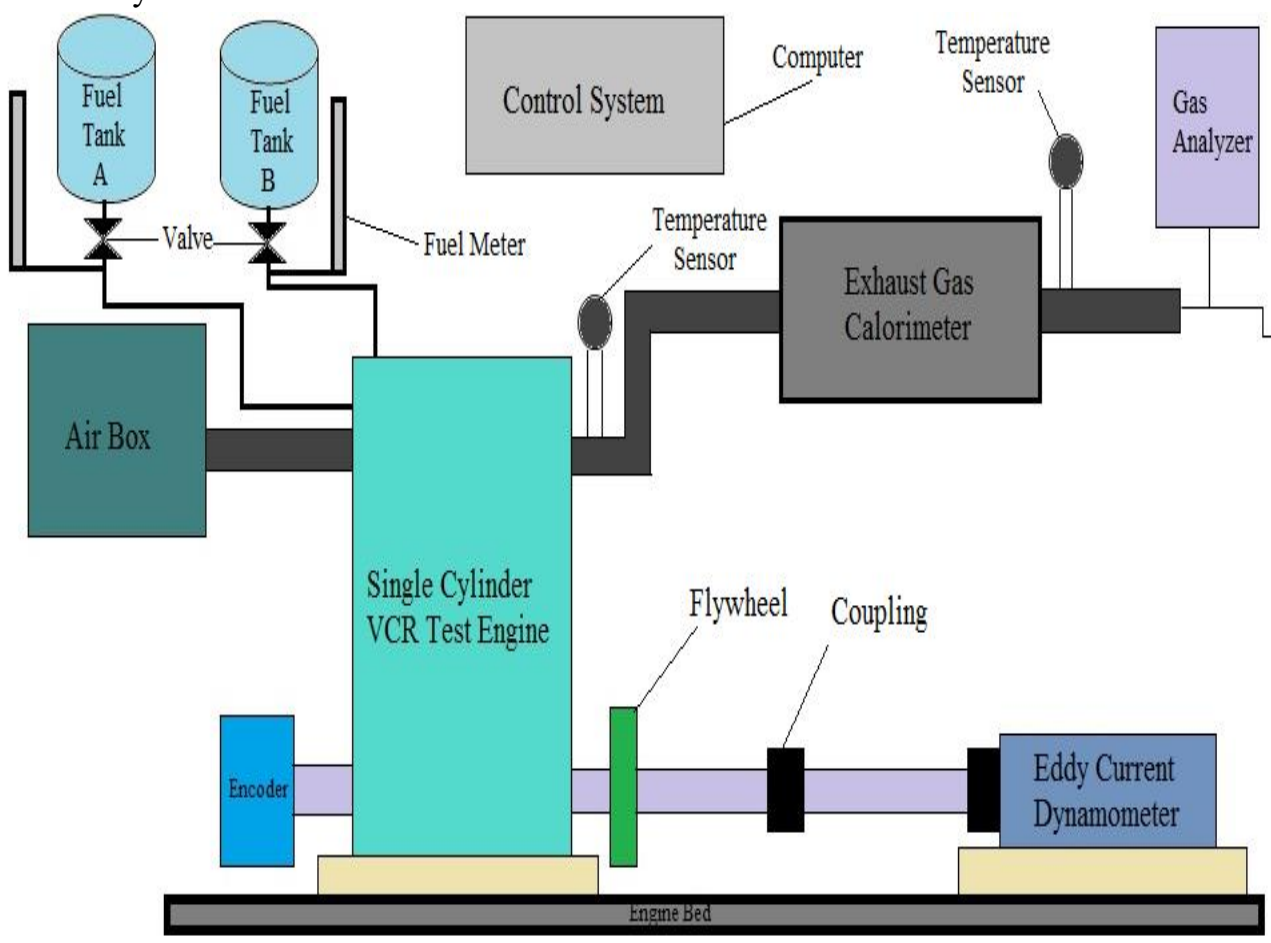

Figure 1. Test engine 
Journal of Thermal Engineering, Research Article, Vol. 6, No. 6, Special Issue 12, pp. 211-225, December, 2020

Table 5. Operating of test engine input

\begin{tabular}{|l|l|}
\hline Parameter & Value \\
\hline Initial pressure & $1.0 \mathrm{bar}$ \\
\hline Cylinder/type & single cylinder/four strokes \\
\hline Initial temperature & $300 \mathrm{~K}$ \\
\hline Piston temperature & $530 \mathrm{~K}$ \\
\hline Liner temperature & $420 \mathrm{~K}$ \\
\hline Head temperature & $500 \mathrm{~K}$ \\
\hline Compression ratio & 17.5 \\
\hline Bore \& stroke & $80 \mathrm{~mm} \& 110 \mathrm{~mm}$ \\
\hline Connecting rod length & $235.0 \mathrm{~mm}$ \\
\hline Fuel injection timing & $23.5^{\circ} \mathrm{CA} \mathrm{b} \mathrm{TDC}$ \\
\hline Fuel spray angle & $70^{\circ}$ \\
\hline Fuel injection pressure & 220 bar \\
\hline Inlet valve open/closed & $4.5^{\circ}$ before TDC/35.5 after BDC \\
\hline Outlet valve open/closed & $35.5^{\circ}$ before BDC/4.5 after TDC \\
\hline Piston & bowl shape \\
\hline Cooling system & water \\
\hline Fuel & Diesel, biodiesel \\
\hline
\end{tabular}

\section{Uncertainty Analysis Of Experiment And Numerical Results}

The uncertainty of instruments and impact of the varying environmental condition. The uncertainties of the instruments are temperature sensor $( \pm 0.15)$, pressure sensor $( \pm 0.5)$, speed sensor $( \pm 1.0)$, crank angle encoder $( \pm 0$. $2)$, load cell $( \pm 0.2)$, burette for fuel measurement $( \pm 1.0)$, smoke $( \pm 1.0), \mathrm{CO} 2( \pm 1.0)$, NOX $( \pm 0.5), \mathrm{CO}( \pm 0.3), \mathrm{HC}$ $( \pm 0.1)$ and $\mathrm{O} 2( \pm 0.3)$. The total percentage of uncertainty in experimental and numerical results depends on magnitude the uncertainties of all the sensors as shown in Table 6 . The overall uncertainty in the experimental setup measurement is $2.2 \%$ of the measured value.

Table 6. Uncertainty of instruments

\begin{tabular}{|l|l|}
\hline Instruments & Uncertainty (\%) \\
\hline Temperature sensor & \pm 0.15 \\
\hline Pressure sensor & \pm 0.5 \\
\hline Speed sensor & \pm 1.0 \\
\hline Crank angle encoder & \pm 0.2 \\
\hline Load cell & \pm 0.2 \\
\hline Burette for fuel measurement & \pm 1.0 \\
\hline Smoke & \pm 1.0 \\
\hline Exhaust gas analyzer & \\
$\mathrm{CO}$ & \pm 0.3 \\
\hline $\mathrm{CO} 2$ & \pm 1.0 \\
\hline $\mathrm{HC}$ & \pm 0.1 \\
\hline $\mathrm{O}_{2}$ & \pm 0.3 \\
\hline $\mathrm{NO}_{\mathrm{x}}$ & \pm 0.5 \\
\hline
\end{tabular}


Journal of Thermal Engineering, Research Article, Vol. 6, No. 6, Special Issue 12, pp. 211-225, December, 2020

\section{Governing Equation Of Diesel-Rk Model}

The governing equation for numerical simulation tool of Diesel-RK model are energy, species, heat release rate, NOX formation, smoke formation using in equation (1-12) $[5,19,20,27,28]$ :

\section{Conservation Of Species}

In The species conservation equation considering the evaluation and destruction of each species has been considered on mass fraction basis, which is described in the following equations (1-2) [39]:

$$
\begin{aligned}
& \frac{\mathrm{dm}}{\mathrm{dt}}=\sum_{j} \dot{m}_{j} \\
& Y_{i}=\frac{m_{i}}{m}
\end{aligned}
$$

\section{Conservation Of Energy}

General conservation of energy equation written by Fivelend and Assanis for a thermodynamic system is shown in equation (3):

$$
\frac{d(m u)}{d t}=-P \frac{d v}{d t}+\frac{d Q_{h t}}{d t}+\sum_{j} \dot{m}_{j} h_{j}
$$

\section{Heat Model}

Multi-zone combustion model used in Diesel-RK model where combustion cylinder heat release rate is defined in four phases are in equation (4-7):

Ignition delay period model

$$
\tau=3.8 \times 10^{-6}\left(1-1.6 \times 10^{-4} . n\right) \sqrt{\frac{T}{P}} \exp \left(\frac{E_{a}}{8.312 T}-\frac{70}{C N+25}\right)
$$

Premixed combustion period model

$$
\frac{d x}{d \tau}=\varphi_{o} \times\left(A_{0}\left(\frac{m_{f}}{V_{i}}\right) \times\left(\sigma_{u d}-X_{0}\right) \times\left(0.1 \times \sigma_{u d}+X_{0}\right)\right)+\varphi_{1} \times\left(\frac{d \sigma_{u}}{d \tau}\right)
$$

Controlled combustion period model

$$
\frac{d x}{d \tau}=\varphi_{1} \times\left(\frac{d \sigma_{u}}{d \tau}\right)+\varphi_{2} \times\left(A_{2}\left(\frac{m_{f}}{V_{c}}\right) \times\left(\sigma_{u}-X\right) \times(\alpha-X)\right)
$$

Burning period model

$$
\frac{d x}{d \tau}=\varphi_{3} A_{3} K_{T}(1-X)\left(\xi_{b} \alpha-X\right)
$$

\section{$\mathrm{No}_{x}$ Formation Model}

$\mathrm{NO}_{\mathrm{x}}$ emission produced within the combustion chamber in diesel engine are grouped in form of nitric oxide (NO) and nitrogen dioxide (NO2) using equation (8-12):

$$
\begin{gathered}
{\left[\mathrm{O}_{2}\right] \leftrightarrow[2 \mathrm{O}]} \\
{\left[\mathrm{N}_{2}\right]+[\mathrm{O}] \leftrightarrow[\mathrm{NO}]+[\mathrm{N}]}
\end{gathered}
$$


Journal of Thermal Engineering, Research Article, Vol. 6, No. 6, Special Issue 12, pp. 211-225, December, 2020

$$
\begin{aligned}
& {[\mathrm{N}]+\left[\mathrm{O}_{2}\right] \leftrightarrow[\mathrm{NO}]+[\mathrm{O}]}
\end{aligned}
$$

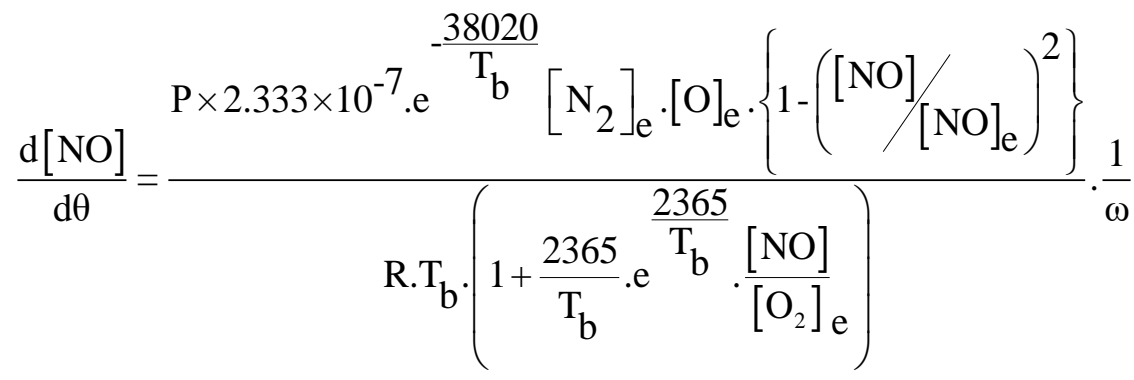

\section{Smoke (Bsn) Model and Particulate Matter (Pm) Formation Model}

PM emission by Alkidas method is selecting for calculation of particulate matter emission which is given in equation (12). PM emission consists of list of species. Soot has a dominant fraction. PM emission as a function of soot emission [15]:

$$
[\mathrm{PM}]=\mathrm{Z}_{\mathrm{PM}} 565\left(\ln \frac{10}{10-\text { Bosch }}\right)^{1.206}
$$

\section{RESULTS AND DISCUSSION}

The comparison of the in-cylinder pressure, heat release rate (HRR), smoke emission between experimental results and numerical results are demonstrated in Figure (2-4). In the experiment and numerical analysis the same operating conditions as shown in Table 5. The trend of results curve was similar during the intake, compression, combustion and exhaust processes and percentage of error deviation between experiment and numerical results as shown in Table 7. The numerical analysis performed using commercial solver Diesel-RK results show that higher cylinder pressure by $4.3 \%$, reduction in maximum heat release rate by $5.9 \%$ and smoke emission by $4.6 \%$. The numerical results and experimental results percentage difference acceptable range. The necessary changes are made in the manuscript at section 3.1 validation simulation tool.

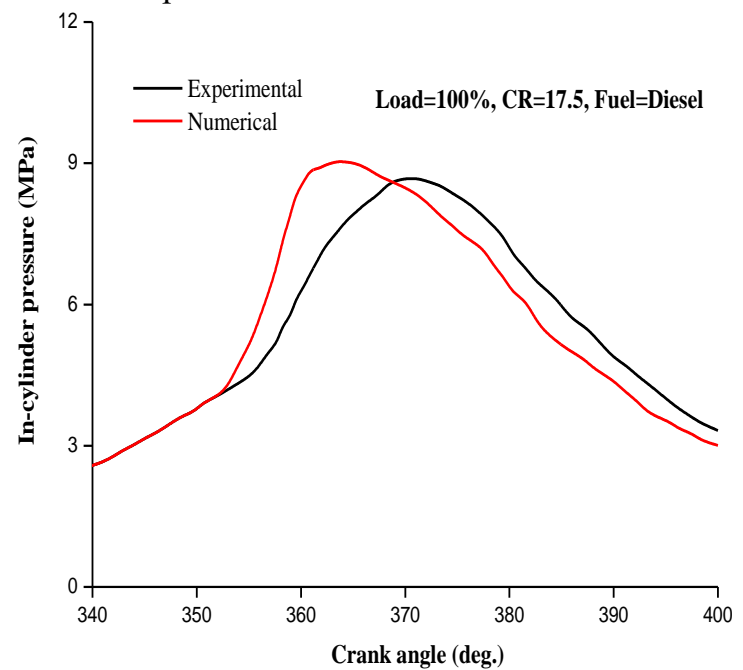

Figure 2. Shows cylinder pressure versus crank angle

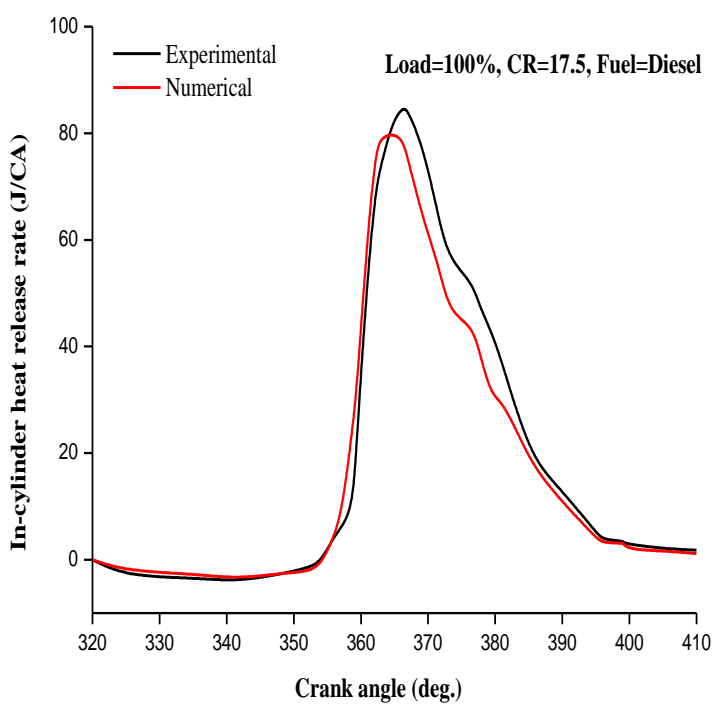

Figure 3. Shows cylinder heat release rate versus load 


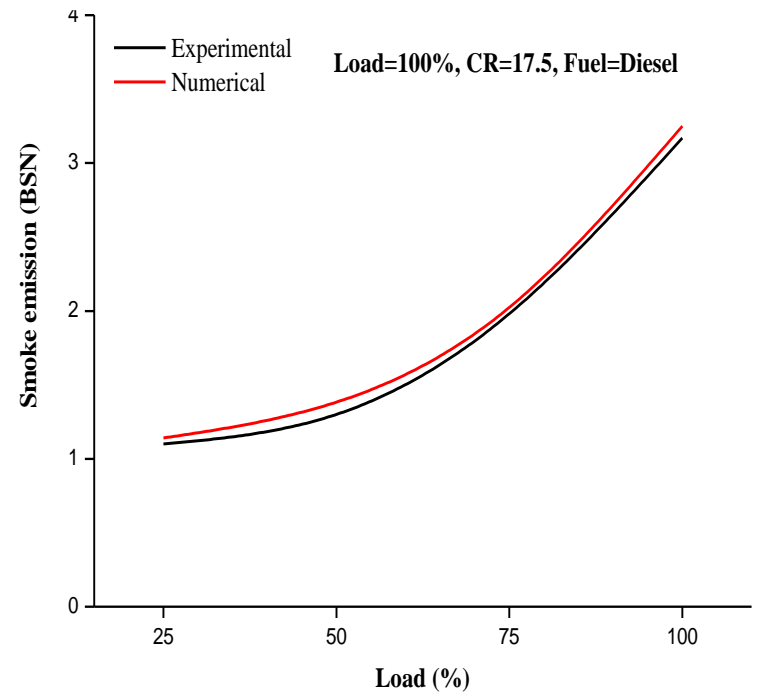

Figure 4. Shows smoke emission versus load

Table 7. Experimental results and numerical results

\begin{tabular}{|l|c|c|c|}
\hline \multicolumn{1}{|c|}{ Characteristics } & Experimental & Numerical & Error (\%) \\
\hline Cylinder Pressure (MPa) & 8.8 & 9.2 & 4.3 \\
\hline Maximum heat release rate (J/CA) & 85.3 & 80.2 & 5.9 \\
\hline Smoke emission (BSN) & 3.1 & 3.25 & 4.6 \\
\hline
\end{tabular}

\section{Emission Parameters}

The numerical results in this paper shows the effects of biodiesels (B20) as characterized by, first, second and third generation biofuels, on the emission characteristics when used as fuel for a direct-injection diesel engine. This section details the related emission characteristics for diesel engine such as smoke, $\mathrm{PM}, \mathrm{CO}_{2}, \mathrm{NO}$ and summary of emission.

\section{Smoke Emission}

Figure 5 shows the variation of smoke emissions with load for first, second and third generation biodiesel. The smoke emission is affected by advancing injection timing, fuel mixing rate, viscosity, oxygen contents, incomplete combustion, the temperature of the combustion zone, engine load, speed, injection pressure [2, 12, 20, 23, 25]. At full load, smoke emission (BSN) is found to be 3.2 for diesel, 3.05, 3.1, 3.12, 3.1 for first-generation biodiesels coconut, palm, rapeseed, and soybean, respectively, 2.85, 3.45, 1.45, 2.89 for second generation biodiesels cottonseed, jatropha, jojoba, and Karanja respectively and 3.05, 3.08, 3.1, 3.06 for third generation biodiesel fish oil, microalgae spirulina, waste oil and animal fats respectively. The minimum smoke emission observed, is $1.45 \mathrm{BSN}$ for jojoba biodiesel, and is about $54.68 \%$ as compared to diesel fuel and other biodiesels. For all the tested biodiesels lesser smoke emissions are obtained as compared to regular diesel fuel. Well, it is the cause due to advanced injection timing and a higher percentage of oxygen contents within biodiesel [30-33]. The fuel-air mixture preparation is good in premixed combustion phase due to oxygen contents, which results in better combustion and low smoke emission [42]. 

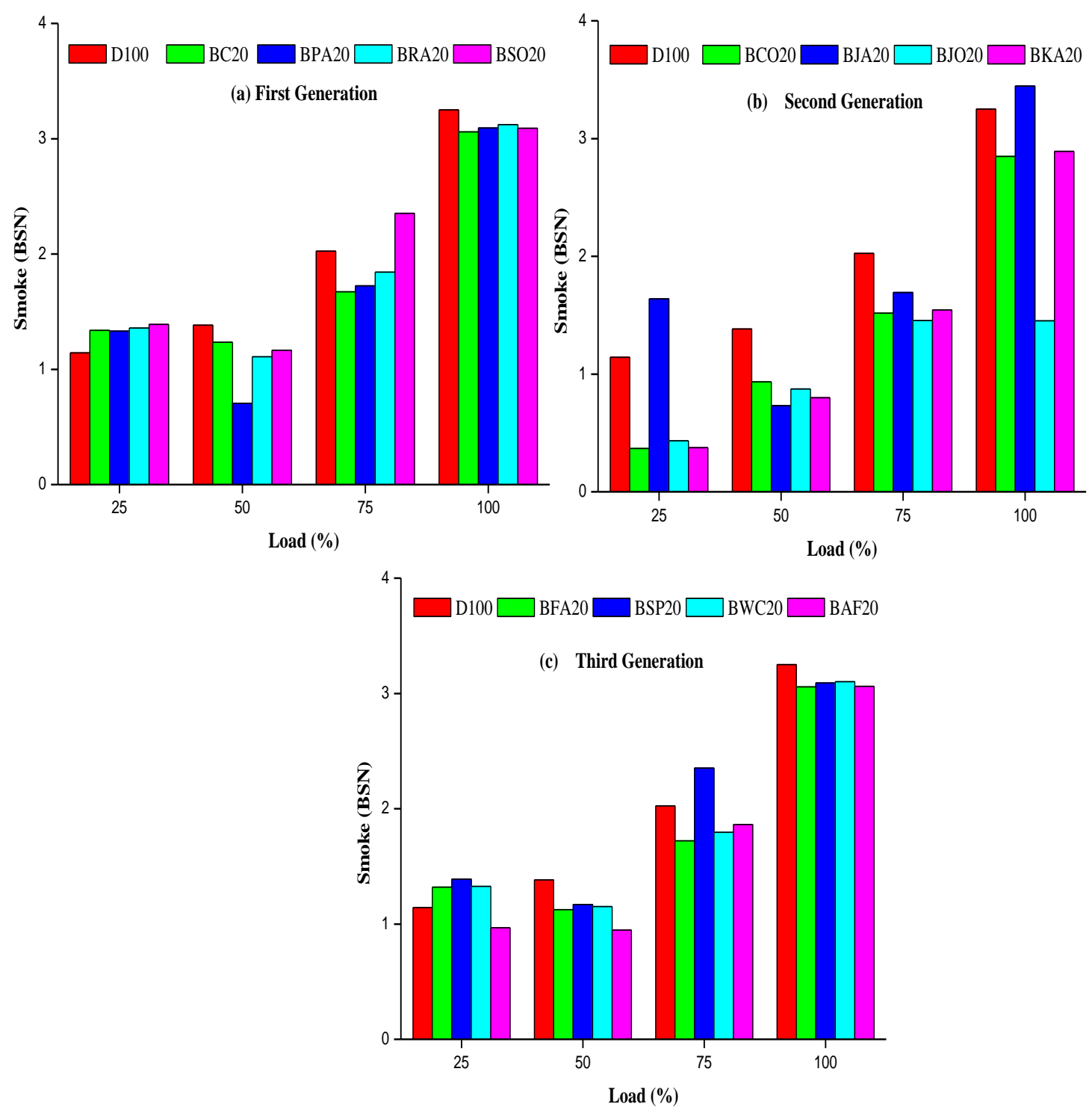

Figure 5. Comparison of variation of smoke emission from first, second and third generation biodiesel at different engine load for B20

\section{Carbon Dioxide Emission}

Figure 6 shows the variation of carbon dioxide $(\mathrm{CO} 2)$ with load for first, second and third generation biodiesels. The $\mathrm{CO} 2$ emission is affected by the heating value of fuel, exhaust gas temperature, oxygen contents, complete combustion, engine load, speed [13, 19, 21]. At CR17.5 on full load condition, CO2 emissions ( $\mathrm{g} / \mathrm{kWh})$ are found 825.5 for diesel, 839.5 for coconut, 844.57 for palm, 828.65 for rapeseed, 836.1 for soybean of the first generation biodiesels, respectively, 846.7 for cottonseed, 823.46 for jatropha, 883.7 for jojoba, 857.6 for Karanja, of the second generation biodiesels respectively and 830.55 for fish oil, 836.24 for microalgae spirulina, 835.46 for waste oil and 834.87 for animal fats of the third generation biodiesel respectively. The $\mathrm{CO} 2$ emissions are obtained higher by $0.38 \%$ for rapeseed, and $0.61 \%$ for fish oil, but are reduced for jatropha curcas by $0.27 \%$ within blend of B20 as compared to diesel fuel. For all tested biodiesel obtained $\mathrm{CO} 2$ emissions are higher as compared to regular diesel fuel, but lesser only for jatropha curcas, due to complete combustion and higher oxygen percentage within the combustion chamber, as compared to diesel fuel. The fuel-air mixture preparation is good in premixed combustion phase due to oxygen contents which results in better combustion and higher CO2 emission [34-36]. 

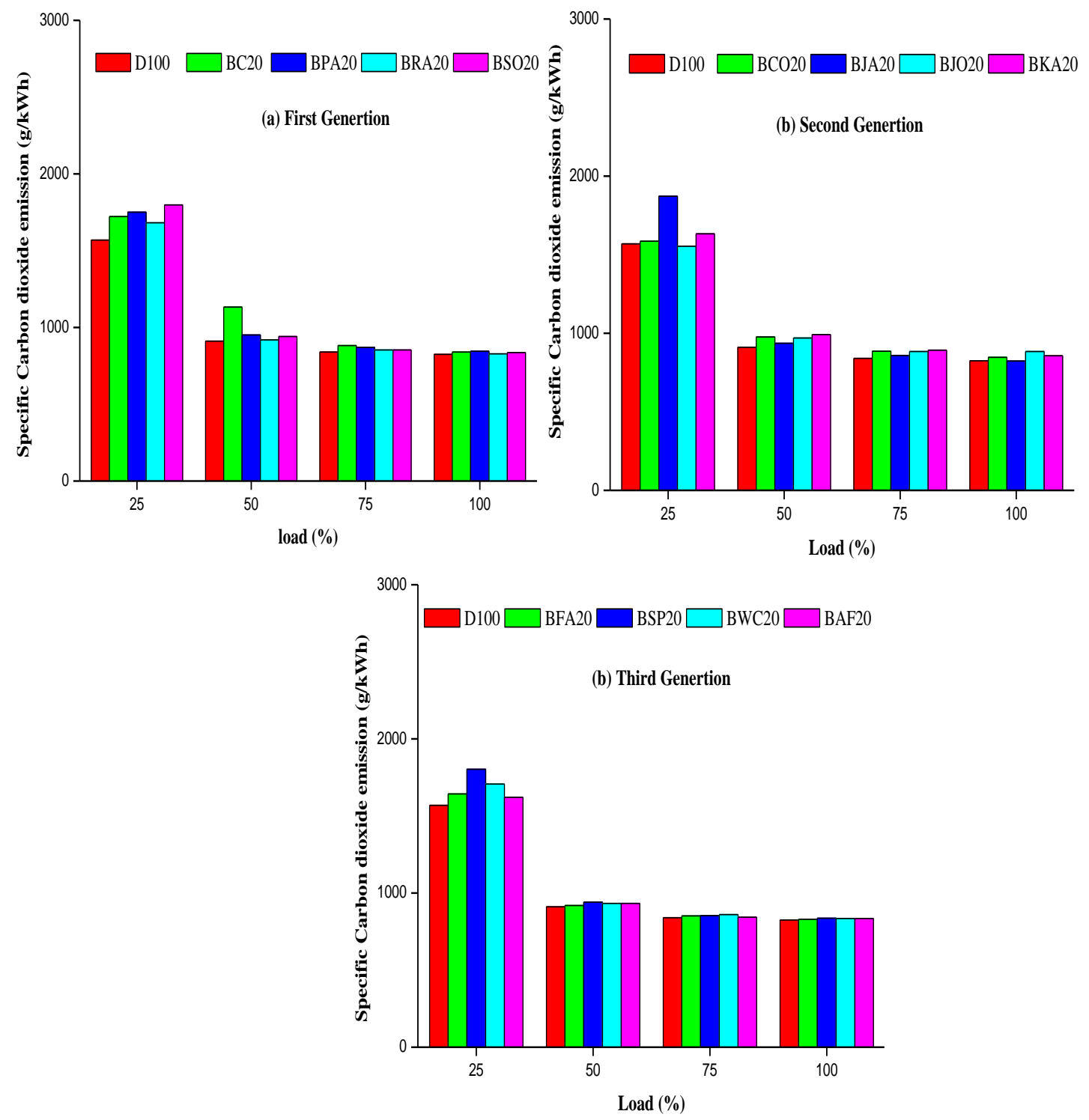

Figure 6. Comparison of variation of $\mathrm{CO}_{2}$ emission from first, second and third generation biodiesel at different engine loads for $\mathrm{B} 20$

\section{Particulate Matter Emission}

Figure 7 shows the specific particulate matter (PM) emission changes at different load for three tested generation biodiesel (B20) samples and diesel. The PM emission is affected by oxygen contents, engine load and speed, injection timing, improper combustion, combustion temperature, and air-fuel mixing rate [1, 5, 19, 20, 27]. The PM emission produced in the combustion chamber due to the improper combustion process. High combustion flame temperature, injection timing, percentage of oxygen, speed and load lead to lower PM emission [37-41]. At CR17.5 with high fuel injection pressure of 220 bar on full load condition, the PM $(\mathrm{g} / \mathrm{kWh})$ was found to be 0.798 for diesel, 0.759 for coconut, 0.776 for palm, 0.772 for rapeseed, 0.767 for soybean (first generation), 0.698 for cottonseed, 0.891 jatropha curcas, 0.383 for jojoba, 0.72 Karanja (second generation) and 0.742 from fish oil, 0.767 spirulina, 0.772 for waste oil, and 0.756 for animal fats (third generation). The minimum PM emission were found to be $4.8 \%$ for coconut (first generation), $52.0 \%$ for jojoba (second generation) and $7.1 \%$ of fish oil (third generation) within a blend of B20 compared to diesel fuel. For all tested biodiesels, lower PM emissions are obtained as compared to regular diesel fuel, due to complete combustion and higher oxygen percentage, compared to diesel fuel. 
The fuel-air mixture preparation is good in premixed combustion phase due to oxygen contents which results in better combustion and lowered PM emission.
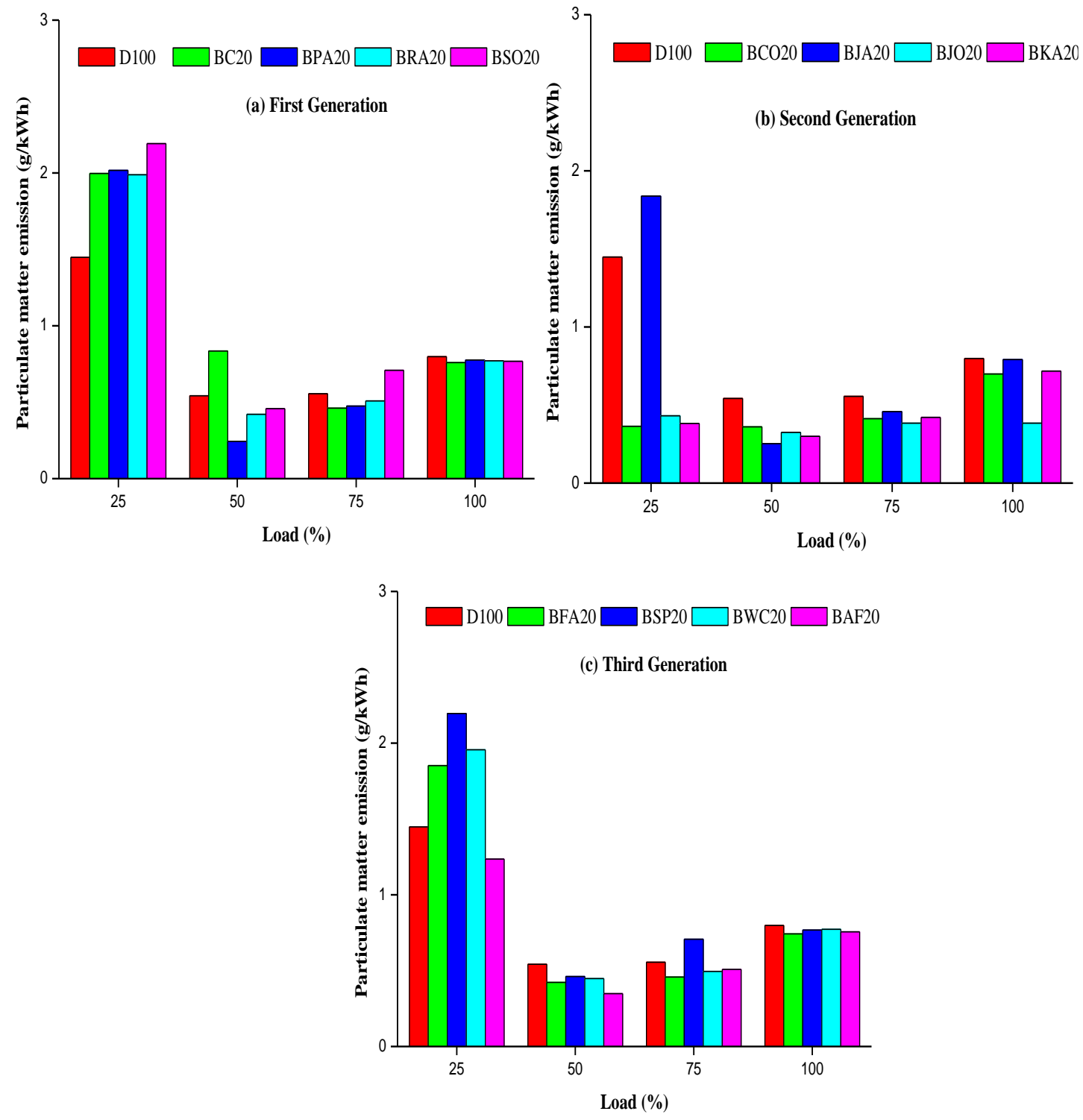

Figure 7. Comparison of variation of PM emission from first, second and third generation biodiesel at different

Nitric Oxide Emission engine load for B20

Figure 8 shows the specific nitric oxide (NO) emission changes at different loads for the three generation biodiesel (B20) samples and diesel. The NO emission is affected by engine load and speed, in-cylinder peak pressure and temperature, calorific value of fuel, viscosity, injection timing, oxygen content, and cetane number $[3,12,13,18$, and 27]. The NO emission is produced within the cylinder due to high temperatures during the combustion process. At CR17.5 with the full load condition, the $\mathrm{NO}(\mathrm{g} / \mathrm{kWh})$ was found to be 16.65 for diesel, 16.63 for coconut, 15.68 for palm, 16.4 for rapeseed, 14.64 for soybean (first generation), 23.4 for cottonseed, 10.3 for jatropha curcas, 28.3 for jojoba, 22.64 for Karanja (second generation) and 18.2 for fish oil, 14.65 for spirulina, 16.12 for waste oil, and 17.81 for animal fats (third generation). The minimum NO emission was found to be $12.0 \%$ for soybean (first generation), $38.2 \%$ for jatropha curcas (second generation) and $12.01 \%$ for spirulina (third generation) within a blend 
of B20, compared to diesel fuel. The NO emission was found higher $41.16 \%$ for jojoba and $8.5 \%$ for fish oil, compared to diesel, due to higher oxygen and viscosity, compared to diesel [43-45].
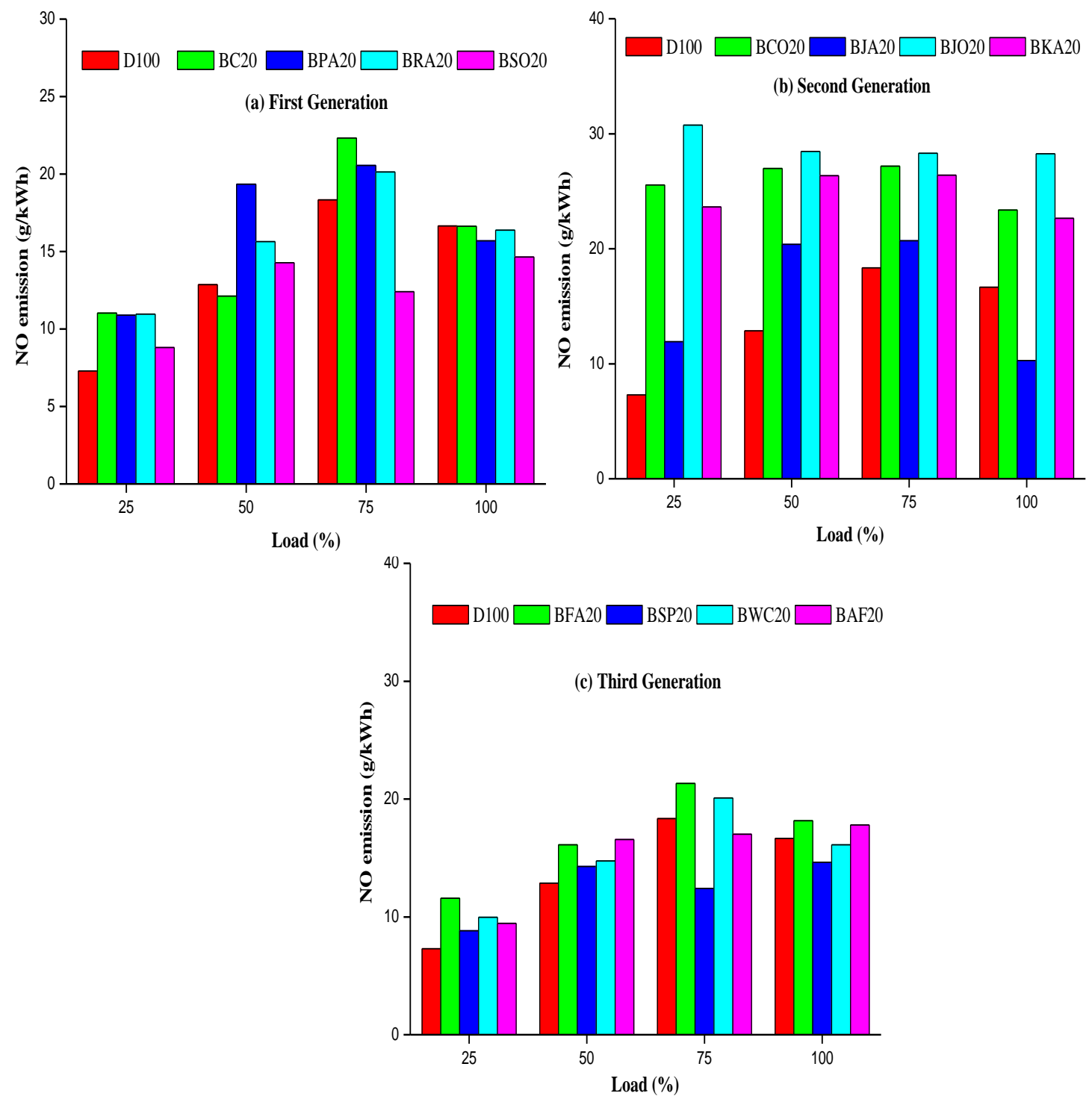

Figure 8. Comparison of variation of $\mathrm{NO}$ emission from first, second and third generation biodiesel at different

\section{Summary of Emissions} engine load for B20

Figure 9 shows the changes in summary of emission (SE) at different loads for three biodiesel generation (B20) samples and diesel. The SE is affected by engine load, combustion temperature, viscosity, oxygen contents. At CR17.5 with the full load condition, the SE was found 5.1 for diesel, 4.91 for coconut, 4.83 for palm, 4.92 for rapeseed, 4.65 for soybean (first generation), 5.66 for cottonseed, 4.44 jatropha curcas, 5.32 for jojoba, 5.63 for Karanja (second generation) and 5.1 for fish oil, 4.65 for spirulina, 4.87 for waste oil, and 5.1 for animal fats (third generation) respectively. The minimum SE emissions were found to be $8.8 \%$ for soybean (first generation), $12.9 \%$ for jatropha curcas (second generation) and $8.8 \%$ for spirulina (third generation) within a blend of B20, compared to diesel, due to higher oxygen and complete combustion, as compared to diesel. Should be clarified from figure 9, the SEs decrease with increase in engine load, shown at the right hand side of $25 \%$. 

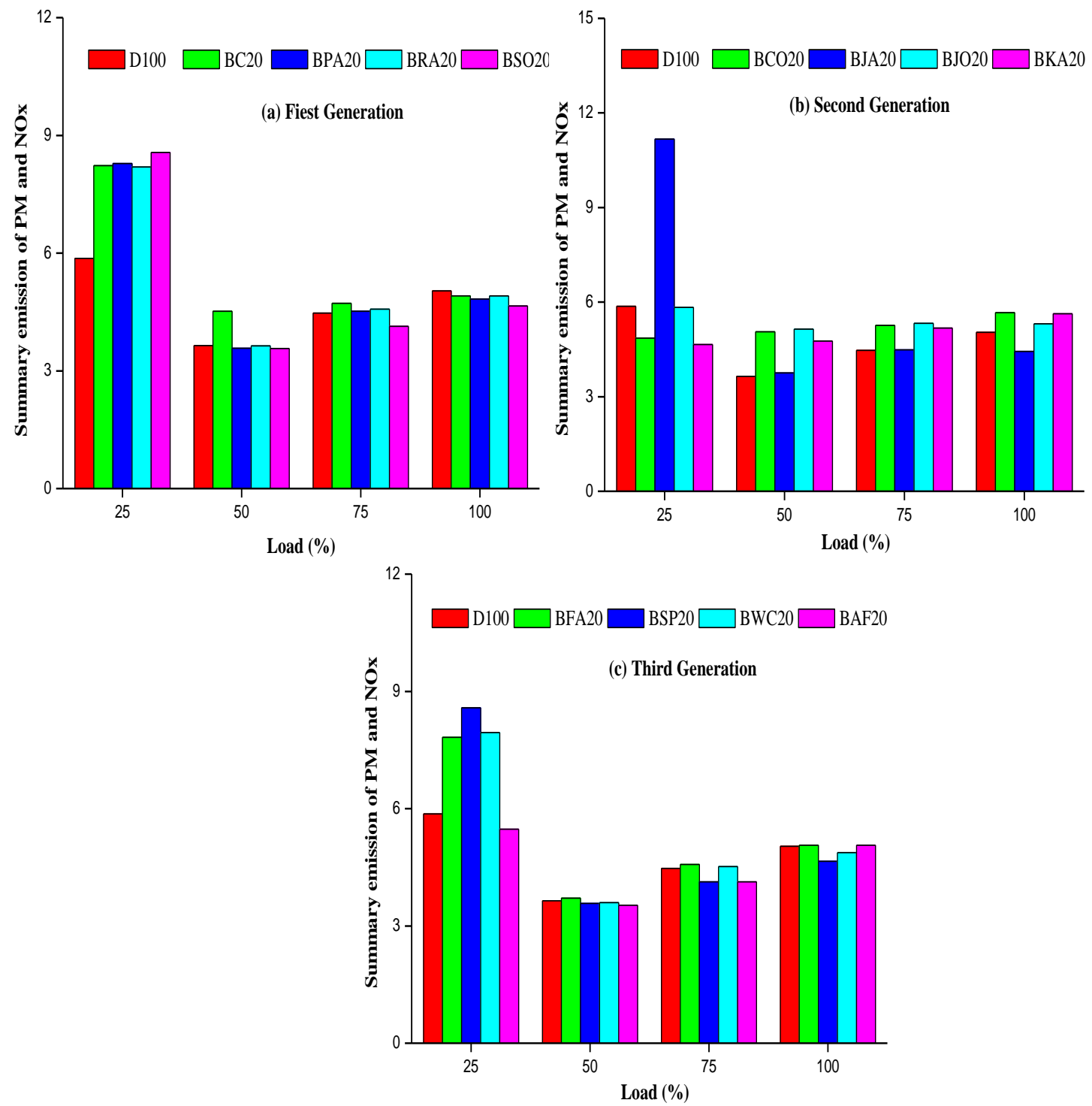

Figure 9. Comparison of variation of SE emissions from first, second and third generation biodiesels at different engine loads for B20

\section{CONCLUSION}

The effects of first, second and third generation biodiesel blends and diesel on the emission characteristics is investigated. The proposed Diesel-RK model will reproduce the smoke, PM CO2, NO and SE trends of different fuels obtained in the single cylinder diesel engine. The critical decisions are as follows.

- Similar numerical and experimental results for tool validation, the numerical results show that reduction in heat release rate and smoke emission, but higher cylinder pressures as compared for diesel.

- The smoke emission is observed to be lower for biodiesel than diesel and increases with an increase in engine load.

- NO emission is lower by $12.0 \%, 38.2 \%$ and $12.01 \%$ for soybean, jatropha curcas and spirulina biodiesel, respectively, but higher by $41.16 \%$ for jojoba and $8.5 \%$ of fish oil, as compared to diesel. It is also observed that the increase of engine load increases the NO emissions at $1500 \mathrm{rpm}$ and CR17.5. 
- Similarly, PM and SE emissions were also lower for testing of first, second and third generation biodiesel than diesel. Engine load can further decrease these emissions.

- Biodiesels showed higher $\mathrm{CO} 2$ emissions by $0.38 \%$ for rapeseed, $0.61 \%$ of fish oil, but the reduction for jatropha curcas about by $0.27 \%$ within a blend of B20, compared to diesel fuel due to complete combustion as compared to diesel.

The numerical analysis results show that soybean (first generation), jatropha curcas (second generation) and spirulina (third generation) biodiesel superior fuel for compression ignition engine due to lower NO emission obtained.

\section{NOMENCLATURE}

\begin{tabular}{|c|c|}
\hline$\tau$ & time (second) \\
\hline $\mathrm{E}_{\mathrm{a}}$ & Activation energy of fuel \\
\hline $\mathrm{dx} / \mathrm{d} \tau$ & Heat release rate $(\mathrm{J} / \mathrm{sec})$ \\
\hline $\mathrm{dx} / \mathrm{dt}$ & Heat release rate $(\mathrm{J} / \mathrm{deg})$. \\
\hline b TDC & Before top dead center \\
\hline $\mathrm{BDC}$ & bottom dead center \\
\hline $\mathrm{BSN}$ & Bosch smoke number \\
\hline CR & Compression ignition \\
\hline PM & Particulate matter \\
\hline rpm & Revolution per minute \\
\hline $\mathrm{MPa}$ & Mega Pascal \\
\hline $\mathrm{NO}$ & Nitric oxide \\
\hline TDC & Top dead center \\
\hline D100 & Pure diesel \\
\hline $\mathrm{B} 20$ & 80 diesel +20 biodiesel \\
\hline $\mathrm{BC} 20$ & Coconut oil biodiesel \\
\hline BPA20 & Palm biodiesel \\
\hline BRA20 & Rapeseed biodiesel \\
\hline $\mathrm{BSO} 20$ & Soybean biodiesel \\
\hline $\mathrm{BCO} 20$ & Cottonseed biodiesel \\
\hline BJA20 & jatropha curcas biodiesel \\
\hline BJO20 & Jojoba oil biodiesel \\
\hline BKA20 & Karanja biodiesel \\
\hline BFA20 & fish oil biodiesel \\
\hline BSP20 & microalgae spirulina biodiesel \\
\hline BWC20 & Waste cooking oil biodiesel \\
\hline BAF20 & animal fats biodiesel \\
\hline $\mathrm{CO}_{2}$ & Carbon dioxide \\
\hline
\end{tabular}

\section{REFERENCES}

[1] Zareh P, Zare AA, Ghobadian B. Comparative assessment of performance and emission characteristics of castor, coconut and waste cooking based biodiesel as fuel in a diesel engine. Energy 2017; 139:883-894. https://doi.org/10.1016/j.energy.2017.08.040

[2] Tamilselvan P, Nallusamy N, Rajkumar S. A comprehensive review on performance, combustion and emission characteristics of biodiesel fuelled diesel engines. Renewable and Sustainable Energy Reviews 2017; 79:1134-1159. https://doi.org/10.1016/j.rser.2017.05.176

[3] Tung C, Ng J, Ahmad S, Rajoo S. Oxygenated palm biodiesel: Ignition, combustion and emissions quantification in a light-duty diesel engine. Energy Conversion and Management 2015;101:317-325. https://doi.org/10.1016/j.enconman.2015.05.058 
[4] Zaharin MSM, Abdullah NR, Naja G, Sharudin H, Yusaf T. Effects of physicochemical properties of biodiesel fuel blends with alcohol on diesel engine performance and exhaust emissions: A review. Renewable and Sustainable Energy Reviews 2017; 79:475-493. http://dx.doi.org/10.1016/j.rser.2017.05.035

[5] Kuleshov A, Mahkamov K. Multi-zone diesel fuel spray combustion model for the simulation of a diesel engine running on biofuel. Power and Energy 2009; 222:309-321. https://doi.org/10.1243/09576509JPE530

[6] Qi DH, Chen B, Zhang D, Lee CF. Optical study on the combustion characteristics and soot emissions of diesel e soybean biodiesel e butanol blends in a constant volume chamber. Journal of the Energy Institute 2015; 89:807-820. https://doi.org/10.1016/j.joei.2015.03.007

[7] Albo PAG, Lago S, Wolf H, Pagel R, Glen N, Clerck M, Ballereau P. Biomass and Bioenergy Density, viscosity and specific heat capacity of diesel blends with rapeseed and soybean oil methyl ester. Biomass and Bioenergy 2017; 96:87-95. https://doi.org/10.1016/j.biombioe.2016.11.009

[8] Ashraful AM, Masjuki HH, Kalam MA, Fattah IMR, Imtenan S, Shahir SA, Mobarak HM. Production and comparison of fuel properties, engine performance, and emission characteristics of biodiesel from various non-edible vegetable oils: A review. Energy Conversion and Management 2014; 80:202-228. https://doi.org/10.1016/j.enconman.2014.01.037

[9] Wang Z, Li L, Wang J, Reitz RD. Effect of biodiesel saturation on soot formation in diesel engines. Fuel 2016; 175:240-248. http://dx.doi.org/10.1016/j.fuel.2016.02.048

[10] Patel RL, Sankhavara CD. Biodiesel production from Karanja oil and its use in diesel engine: A review. Renewable and Sustainable Energy Reviews 2017; 71: 464-474. http://dx.doi.org/10.1016/j.rser.2016.12.075

[11] Huzayyin AS, Bawady AH, Rady MA, Dawood A. Experimental evaluation of Diesel engine performance and emission using blends of jojoba oil and Diesel fuel. Energy Conversion and Management 2004; 45:20932112. https://doi.org/10.1016/j.enconman.2003.10.017

[12] Gnanasekaran S, Saravanan N, Ilangkumaran M. Influence of injection timing on performance, emission and combustion characteristics of a DI diesel engine running on fish oil biodiesel. Energy 2016; 116:1218-1229. https://doi.org/10.1016/j.energy.2016.10.039

[13] Gharehghani A, Mirsalim M, Hosseini R. Effects of waste fish oil biodiesel on diesel engine combustion characteristics and emission. Renewable Energy 2017; 101:930-936. https://doi.org/10.1016/j.renene.2016.09.045

[14] Wei L, Cheung CS, Ning Z. Influence of waste cooking oil biodiesel on combustion, unregulated gaseous emissions and particulate emissions of a direct-injection diesel engine. Energy 2017; 127:175-185. http://dx.doi.org/10.1016/j.energy.2017.03.117

[15] Sander A, Ko MA, Kosir D, Milosavljevi N. The influence of animal fat type and purification conditions on biodiesel quality. Renewable Energy 2018; 118:752-760. https://doi.org/10.1016/j.renene.2017.11.068

[16] Nautiyal P, Subramanian KA, Dastidar MG. Production and characterization of biodiesel from algae. Fuel Processing Technology 2014; 120:79-88. https://doi.org/10.1016/j.fuproc.2013.12.003

[17] Espinosa M, Canielas L, Silvana M, Moraes A, Schmitt C, Assis R, Bastos E. Beef tallow biodiesel produced in a pilot scale. Fuel Processing Technology 2009; 90:570-575. https://doi.org/10.1016/j.fuproc.2009.01.001

[18] Yatish KV, Lalithamba HS, Suresh R, Hebbar HRH. Optimization of bauhinia variegata biodiesel production and its performance, combustion and emission study on diesel engine. Renewable Energy 2018; 122:561-575. https://doi.org/10.1016/j.renene.2018.01.124

[19] Rajak U, Nashine P, Verma TN. Characteristics of microalgae spirulina biodiesel with the impact of n-butanol addition on a CI engine; Energy 2019; 189:116311. doi.org/10.1016/j.energy.2019.116311

[20] Rajak U, Nashine P, Verma TN. Effect of Fuel Injection Pressure in a Diesel Engine using Microalgae-Diesel Emulsion; International Journal of Engineering and Advanced Technology (IJEAT) 2019; 8(3):263-271

[21] Al-lwayzy SH, Yusaf T. Diesel engine performance and exhaust gas emissions using Microalgae Chlorella $\begin{array}{lllll}\text { protothecoides } & \text { biodiesel. } & \text { Renewable } & \text { Energy } & \text { 2017; }\end{array}$ https://doi.org/10.1016/j.renene.2016.09.035

[22] Yüksel B. Effects of higher ratios of n-butanol addition to diesel e vegetable oil blends on performance and exhaust emissions of a diesel engine. Journal of the Energy Institute 2015; 88:209-220. https://doi.org/10.1016/j.joei.2014.09.008

[23] Imdadul HK, Masjuki HH, Kalam MA, Zulkifli NWM, Alabdulkarem A, Rashed MM, How HG. Higher alcohol - biodiesel - diesel blends: An approach for improving the performance, emission, and combustion of a light-duty diesel engine. Energy Conversion and Management 2016; 111:174-185. https://doi.org/10.1016/j.enconman.2015.12.066 
[24] Mahmudul HM, Hagos FY, Mamat R, Adam AA, Ishak WFW, Alenezi R. Production, characterization and performance of biodiesel as an alternative fuel in diesel engines - A review. Renewable and Sustainable Energy Reviews 2017; 72: 497-509. https://doi.org/10.1016/j.rser.2017.01.001

[25] Elsanusi OA, Roy MM, Sidhu MS. Experimental Investigation on a Diesel Engine Fueled by Diesel-Biodiesel Blends and their Emulsions at Various Engine Operating Conditions. Applied Energy 2017; 203:582-593. https://doi.org/10.1016/j.apenergy.2017.06.052

[26] Rajak U, Nashine P, Verma TN. Numerical study on emission characteristics of a diesel engine fuelled with diesel-spirulina microalgae-ethanol blends at various operating conditions. Fuel 2020; 262:116519. doi.org/10.1016/j.fuel.2019.116519.

[27] Rajak U, Nashine P, Verma TN. Effect of spirulina microalgae biodiesel enriched with diesel fuel on performance and emission characteristics of CI engine. Fuel 2020; 268:117305. doi.org/10.1016/j.fuel.2020.117305

[28] Rajak U, Nashine P, Verma TN. Effect of fuel injection pressure of microalgae spirulina biodiesel blends on engine characteristics; Journal of Computational \& Applied Research in Mechanical Engineering 2019. https://doi.org/10.22061/jcarme.2019.4767.1578

[29] Hotti SR, Hhebbal OD. Biodiesel production and fuel properties from non-edible champaca (michelia champaca) seed oil for use in diesel engine. Journal of Thermal Engineering 2015; 1(1):330-336.

[30] Karagöz Y, Köten H. Effect of different levels of hydrogen + LPG addition on emissions and performance of a compression ignition engine. Journal of Thermal Engineering 2019; 5(2): 58-69.

[31] Al-mawali J, Dakka SM. Numerical analysis of flame characteristics and stability for conical nozzle burner. Journal of Thermal Engineering 2019; 5(5):422-445.

[32] Kurien C, Srivastava AK. Review on post-treatment emission control technique by application of diesel oxidation catalysis and diesel particulate. Journal of Thermal Engineering 2019; 5(2):108-118.

[33] Joshi MP, Thipse SS. Combustion analysis of ci engine fuelled with algae biofuel blends. Journal of Thermal Engineering 2019; 5(6):214-220.

[34] Karagoz Y. Emissions and performance characteristics of an SI engine with biogas fuel at different $\mathrm{CO} 2$ ratios. Journal of Thermal Engineering 2019; 5(6):131-140.

[35] Salam S, Verma TN. Analysis of significance of variables in IC engine operation: an empirical methodology; Energy Conversion \& Management 2020; 207: 112520. https://doi.org/10.1016/j.enconman.2020.112520

[36] Rajak U, Nashine P, Verma TN, Pugazhendhi A. Performance and emission analysis of a diesel engine using hydrogen enriched n-butanol, diethyl ester and Spirulina microalgae biodiesel. Fuel 2020; 271; 117645. doi.org/10.1016/j.fuel.2020.117645

[37] Singh TS, Verma TN. Biodiesel production from Momordica Charantia (L.): Extraction and engine characteristics; Energy 2019; 189: 116198. doi.org/10.1016/j.energy.2019.116198

[38] Singh TS, Verma TN. Impact of Tri-Fuel on compression ignition engine emissions: Blends of waste frying oil-alcohol-diesel; Methanol and the Alternate Fuel Economy; Springer 2019; 135-156; ISBN: 978-981-132982-1. https://doi.org/10.1007/978-981-13-3287-6_7

[39] Shrivastava P, Verma TN, Samuel OD, Pugazhendhi A. An experimental investigation on engine characteristics, cost and energy analysis of CI engine fuelled with Roselle, Karanja biodiesel and its blends. Fuel 2020; 275: 117891. https://doi.org/10.1016/j.fuel.2020.117891

[40] Sharma DK, Verma TN. Characteristics of fish oil biodiesel with the impact of diesel fuel addition on a CI engine; Journal of Computational \& Applied Research in Mechanical Engineering 2019; 10(1):245-256. doi: 10.22061/jcarme. 2019.4737 .1571

[41] Salam S, Verma TN. Identifying empirically important variables in IC engine operation through redundancy analysis; Lecture Notes in Mechanical Engineering (LNME) - Springer 2020; 45-51, ISBN 978-981-15-12001. doi.org/10.1007/978-981-15-1201-8_6

[42] Shankar S, Astagi HV, Hotti SR, Hebbal O. Effect of exhaust gas recirculation (EGR) on performance, emissions and combustion characteristics of a low heat rejection (LHR) diesel engine using pongamia biodiesel. Journal of Thermal Engineering 2016; 2(6):1007-1016.

[43] Abay K, Colak U, Yüksek L. Computational fluid dynamics analysis of flow and combustion. Journal of Thermal Engineering 2018; 4(2):1878-1895.

[44] Gül MZ, Köten H, Yılmaz M, Savcı LH. Advanced numerical and experimental studies on CI engine emissions. Journal of Thermal Engineering 2018; 4(4):2234-2247.

[45] Koten H. Performance analysis of a diesel engine within a multi. Journal of Thermal Engineering 2018; 4(4): $2075-2082$. 